\title{
Using Digital Video Technology Supports the Researcher to Be a Play Participant in Children's Play
}

\author{
Anamika Devi \\ Melbourne City Institute of Education, Australia \\ anamika.devi@rmit.edu.au \\ Coreena Makris \\ Melbourne City Institute of Education, Australia \\ coreena.makris@mcie.edu.au \\ Maryann James \\ Melbourne City Institute of Education, Australia \\ maryann.james@mcie.edu.au
}

\begin{abstract}
Using digital video technology for collecting research data is becoming a popular qualitative method in social science research. This article explores how digital video technology could be an analytical tool for a researchers and how this tool supports the researcher to actively engage in children's play. The study uses a culturalhistorical methodological approach and Hedegaard's "dialectical-interactive research approach" (2008b, p. 43) to analyse the data. Three different examples of a focus child, Apa, and the researcher's participation in different play vignettes will be presented. It has been found that a researcher needs to be really skillful when taking the "doubleness approach" (Hedegaard 2008d, p. 203) of simultaneously taking part in the children's play and video recording the moments of play. The findings also show that positioning the camera in a way where it can capture the play moments and participants' expressions, enabled the researcher to be an active play participant in the play and to understand the play theme from the children's perspectives

(C) ANAMIKA DEVI, COREENA MAKRIS \& MARYANN JAMES, 2O2O | DOI:10.1163/23644583OO4O1O19 | THIS IS AN OPEN ACCESS ARTICLE DISTRIBUTED UNDER THE TERMS OF THE CC-BY 4.0 LICENSE.
\end{abstract}


without taking the authority away from the children. The authors argue that using digital video technology could be a useful analytical tool for the researcher to understand the participants' perspectives and the research context itself.

\section{Keywords}

cultural-historical methodology - digital video technology - position - doubleness approach - motives and demands

\section{$1 \quad$ Introduction}

According to cultural-historical theory, it is important for the researcher to understand the process of a child's development rather than emphasize the product of development. The researcher needs to focus on a holistic model of development where a child's psychological, biological and cultural dimensions need to be observed in a dialectical relationship (Vygotsky 1997a). Vygotsky (1997a) stated that "the process of cultural development itself must be understood as a change in the basic original structure and the development of new structures" (p.83). According to cultural-historical research, the researcher should not only focus on the objective of the study, but it is also important to understand the research tools and the position of the researcher in the research process (Fleer and Veresov 2018). Culturalhistorical researchers have claimed through their methodological research, that using video methodology not only opened up the possibility to interpret the fleeting moments, nonverbal interactions and physical positioning of the research participants but also allowed the researcher to understand the entire social situation (Fleer and Ridgway 2014; White 2016). Using digital video cameras and different apps helps them to collect and analyse data, which was not readily available in Vygotsky's time, opening up the new possibilities to understand the child's development as a process (Fleer and Veresov 2018). A long period of investigation by Hedegaard and Fleer (2013), showed video observation gave them the scope to capture the children's everyday activities, for example, meal time routine, bed time routine, walking to school, being at school, walking home, doing homework and other activities over the period of 12 months. Capturing these transitional moments was not an easy task to do but it was only possible because of video technology which allowed them to analyse the societal values, institutional practice and intentions of research participants holistically. It has been

VIDEO JOURNAL OF EDUCATION AND PEDAGOGY 4 (2020) $\quad$ 1-28 
mentioned in cultural-historical research that a child needs to be observed holistically in order to analyse the social context of the child (Hedegaard 2008). Therefore, considering Vygotsky's principles and concepts for researching children within an Early Childhood Education and Care (ECEC) setting is an important (Fleer and Veresov 2018; Fleer and Ridgway 2014) criterion. We need to observe children in different settings such as, home, preschool, long day care, school and community care etc. where children attend in their everyday life. We should also take into account how we could use digital technology as a cultural tool (Fleer and Veresov 2018) to capture everyday activities of young children to understand their learning and development in ECEC settings. In the 21st century, children are familiar with mobile phones, ipads, video cameras, still cameras etc. which could open up the opportunity for educators to use visual technology, for capturing spontaneous moments of learning in children's play and for developing their planning in ECEC settings.

The CHT researchers used digital video technology for capturing the moments of developmental conditions of young children in various settings and various situations (Devi, Fleer and Li 2018; Fleer and Ridgway 2014; Johansson and White 2011; Hao and Fleer 2016; Li 2014; Quinones 2014; Ridgway 2018). For example, Devi el al. (2017) found video technology was a very useful research tool to follow how young children transition from childinitiated play to a teacher-initiated activity. The researchers were able to capture the motive orientation of teacher and children in the particular transitional moment by using video camera in a preschool setting. Another group of researchers have found that a video camera helped them to understand young children's emotional language and cognitive development in their home environment (Chen 2015; Hao and Fleer 2016; Li 2014; Sikder and Fleer 2015). Visual methodology has been used as an observational tool to explore the interaction process and many different forms of expressing non-verbal emotions and meanings of infant-toddlers (Quiñones and Fleer 2011; White 2011). To capture two year olds' verbal and non-verbal communications with teachers and older peers, White (2016) used the polyphonic video approach in understanding young children's learning process in educational setting. The polyphonic approach captures participants' perspectives from the three different visual fields (White 2016; White et al. 2013; White et al. 2019a and 2019b), for example

1. The visual field of teachers where they used video-recorder glasses to record their pedagogical experiences

VIDEO JOURNAL OF EDUCATION AND PEDAGOGY 4 (2020) $\quad \mathbf{1 - 2 8}$ 
2. The movement field of a 2-year-old child by using swivel tracking cameras with microphones to record the movements of the child

3. A $360^{\circ}$ camera captured the wider environment and included the position of the child within the educational setting.

White (2016) found that video technology gave her the opportunity to notice the young child's and teacher's involvement in effective dialogues through body gestures, movements, verbal talk and sounds within the educational settings.

A study by Quiñones (2016) who explored the question of how can emotions be captured and how can the field research data can be presented visually while this is captured what role does the researcher have? She found visual methodology allowed her to capture participants' emotions. Capturing participants' emotions is not an easy thing to do, therefore the researcher took a tactile path through the experience, and was affected and touched by the experience. To understand the participant's emotional changes, the researcher took various roles for example a teacher, and a friend in different research contexts. A number of studies have focused on developing an understanding of the use of this visual technology as a methodological tool for researchers to document children's play and learning in ECEC settings. Apart from the research by Brian (2010) and Quiñones (2016), in our literature review, we have not found any other research papers that particularly focused on the researcher's role and position of the researcher during filming the moments. Brian (2010) argued that beside assisting children in setting up the activity, the adult also needs to participate and directly influence play in order to model social and play skills. Therefore, the aim of this paper is to seek how digital video technology could be an analytical tool for the researcher and how this tool supports the researcher become an active participant in children's play.

In order to answer these research questions, the paper conceptualises the position of the researcher and the position of the video camera in children's play and discusses the cultural-historical methodological approach in the next section. The theoretical section is followed by details of the study design, then the findings and discussion are presented. 

Young Children

According to maturational theory, children need to be at a certain age before achieving any developmental milestone, but the theory was oblivious to seeing the child's development as a process where culture is a significant phenomenon. However, Vygotsky (1997) argued about this maturational view and stated that "the process of cultural development itself must be understood as a change in the basic original structure and the development of new structure" (p.83). Cultural-historical research provides a lens for the researcher to look at a child's development in its movement (Veresov 2014b; Vygotsky 1997a). This movement refers to all changes and processes of human development from the beginning to the end of life (Vygotsky 1997a). As previously discussed, Vygotsky (1978) used the metaphor of "buds', "flowers", and "fruits" (p. 86) to describe the process of development and the maturing and matured process. He did not see human development in the product and static sense, rather he saw human development as a whole dynamic process. By using cultural-historical methodology, the CHT researchers analyse the process through which development takes place from the buds to the fruits and from the very beginning to the end (Veresov 2014). As Vygotsky (1997b) argues, "What must interest us is not the finished result, not the sum or product of development, but the very process of genesis (origin) or establishment of the higher form caught in a living aspect" (p. 71).

Video observation can capture the dynamic process of child's development and child's engagement with their social institutions which was evident from Hedegaard's and Fleer's 2013 book. Using video observation, it gave them the scope to see how children's everyday activities, play, and the demands of both family and educational contexts influence children's learning and development (Hedegaard and Fleer 2013). Children are familiar with video cameras or mobile phones in their everyday life. So a video camera could be a cultural tool for ECEC educators to capture everyday activities and play moments of the children (Fleer and Veresov 2018). Fleer and Veresov have argued that "not every research tool is a cultural tool and also not every cultural tool could be a research tool", but a video camera is a "double possibility" because it could capture the development of children and at the same time help in the development of the child (2018, p. 239). After doing an extensive literature review in the topic of using video technology in everyday research, we have found that a number of culturalhistorical researchers such as Hedegaard and Fleer (2008); Fleer and Ridgway

VIDEO JOURNAL OF EDUCATION AND PEDAGOGY 4 (2020) $\quad \mathbf{1 - 2 8}$ 
(2014); White (2011) and White et al. (2019a) claimed that video technology gives opportunities to the researcher

- To capture everyday practices and activities in a naturalistic setting.

- To understand the child's holistic development as a process

- To gain a depth of understanding about the nature of the participants' facial expression, and non-verbal and verbal interaction process

- To go back to the data to analyse again and again for evaluation and interpretation

- To think about new research questions

For example, White (2016) found using four cameras in data collection, gave her scope to interpret data from different participants' perspectives. It also allowed her a greater potential to capture the event's complexity which might not possible in one single camera lens. So it is showing that video technology supports the cultural-historical researchers to analyse the child holistically where culture and historical backgrounds are enacted. To understand the methodological approach of using video technology in cultural-historical theory, it is important to understand the researcher's role and position in the research site.

\section{Doubleness Approach of the Researcher}

In order to conceptualise the child's development as a whole, the culturalhistorical researcher studies the conditions as well as how the child participates in activities and interacts with other people in the community (Fleer 2008; Hedegaard 2008b). Grounded by cultural-historical theory, Hedegaard (2008a) developed a dialectical-interactive research methodology, that captures a "wholeness" and "dynamic" approach to research. In the cultural-historical wholeness approach, the researcher can study different aspects of children's development but these aspects should be considered in relation to the whole child within the different institutional settings (Hedegaard 2012). As illustrated in Figure 1, the research aims can be achieved by considering the situational explanation, intentional orientation, and methodological tools (Hedegaard 2012). Each element is dialectically interlinked with the other, where 


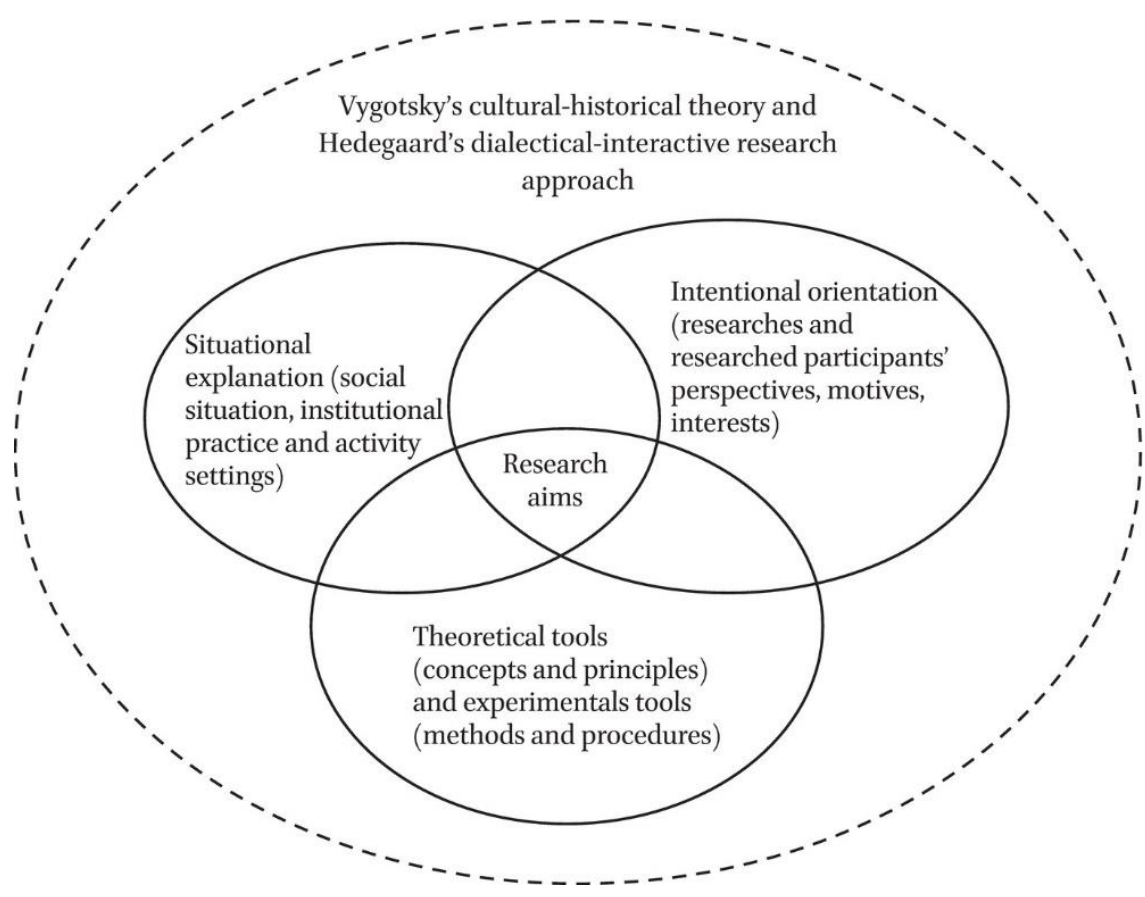

FIGURE 1 Relation between theory and methods in this research

- the situational explanation refers to participants' social situations, their institutional practices and how they create the activity settings in their everyday life,

- the intentional orientation represents the research participants' perspectives and motives, which are important to the researcher to meet the research aim,

- the researcher also uses theoretical tools (for example, concepts and principles) and experimental tools (for example, methods and procedures) to answer the research questions.

To observe the children's interaction closely with families and teachers, the dialectical-interactive research approach requires the researchers to be in partnership with the research participants by participating in relevant social settings (Hedegaard 2008b). This way, the researcher can observe all the participants' perspectives, for example, what type of strategies the adults employ in play pedagogy to support children's learning and development. In this sense, the researcher has a dual role, where the researcher enters into the activity settings with the research participants to understand the 
everyday practices, and also constructs the protocol writing through interpreting activities (Hedegaard 2008c). Rogoff (2003) and Quiñones (2014) reflected on their own position as a researcher while studying in different communities. They found the community accepted their role as a teacher rather than as a psychological researcher undertaking field observation. Quiñones (2014) has also found that another role of the researcher in research field is as a friend of research participants. According to her "through participating affectively and understanding the affective positioning, the researcher unpacks what it means to be more than a participant in the research field" (Quiñones 2014, p. 127). This approach is different to traditional research. In traditional research, the researcher mainly positions himself/herself as a "fly on the wall", and is therefore situated outside the research context, rather than interacting with the research participants and relating to the research participants (Li 2014). The cultural-historical researcher needs to be very skillful to handle the camera where the camera needs to be 'above the waist' so that she/he can interact with the participants. A traditional approach of handling the camera is over the eye, however, the position 'above the waist' actually allows the researcher to talk and make eye contact with participants (Quiñones 2014, p. 118).

As an active researcher in the research field, the researcher positions himself/herself mainly as an observer, taking video observations in the family home and preschool settings. However, the researcher occasionally is involved in the activity when necessary. For example, the researcher only takes an active position in helping parents and teachers, or supporting children's interest when needed. It is important to keep in mind not to take the authority of the other participants or direct the play situation, but rather engage with participants as a member of the community by letting them know what the actual role of the researcher is (Hedegaard 2008d). It is not easy but rather challenging. The researcher needs to have a clear understanding of what he/she should do when there is a conflict between being a researcher and a participant. For example, in some cases, the focus children asked the first author researcher for active involvement in their play when the researcher was video recording an interesting play situation. The first author researcher did not make the child upset by not responding to him/her, but neither did she stop the recording. Rather, she used different techniques e.g. "holding the camera above the waist', or 'placing the camera on a tripod' to continue the filming to maintain the roles as both researcher and participant in the activity. The researcher did not dismiss her position but rather participated in the situation in such a way that gave her the scope to understand the participants' motives and social interactions. Hedegaard

VIDEO JOURNAL OF EDUCATION AND PEDAGOGY $4(2020) \quad$ 1-28 
(2008a) argues "the social scientist both participates in activities in everyday settings paying attention to her needs and motives and, at the same time, includes these activities as her object of study - with the focus on the participants' motives, projects and intentions" (p. 202). To fulfill the motives, both the researcher and the research participants put demands upon each other (Quiñones 2014). Fleer (2008) has suggested these motives and demands of research participants can be captured in motion using digital video observations.

\section{$4 \quad$ Methodological and Ethical Consideration}

\subsection{Research Participants and Study Design}

The data were collected from the first author's doctoral study. There are four Indian-Australian immigrant families participated in this study. The children were 4-5 years old during the data collection period. Their parents had immigrated to Australia more than 5 years ago (time duration calculated during the data collection period) but all the focus children were born in Australia. Inspired by the visual methodology, the researcher collected data using various research tools and methods, such as a video camera, a still camera, an audio recorder, a tripod, photographs, artifacts and field notes (Fleer and Ridgway 2014). Video camera is a useful tool that gives the opportunity to capture every moments of everyday practices, interactions process, facial expressions, physical positions and roles of the research participants. It allows the researcher to re-visit the video clips again and again for deep analysis (Fleer 2008) which is not possible by still photographs and field notes. In total 82 hours' video data, 403 images, and four hours' interview data collected from two preschool and four focus families over a period of eight weeks. See the detail in Table 1.

TABLE 1 The details of the data collection

\begin{tabular}{|c|c|c|c|c|c|c|}
\hline $\begin{array}{l}\text { Two } \\
\text { preschools } \\
\text { (pseudonyms } \\
\text { were used) }\end{array}$ & $\begin{array}{l}\text { Focus } \\
\text { children } \\
\text { (pseudonyms } \\
\text { were used) }\end{array}$ & $\begin{array}{l}\text { Video } \\
\text { data }\end{array}$ & Images & Interview & & Portfolios \\
\hline $\begin{array}{l}\text { Possum } \\
\text { preschool }\end{array}$ & JJ (boy) & $\begin{array}{l}\text { Home } \\
-6 \text { hours } \\
\text { Preschool } \\
-22 \text { hours }\end{array}$ & 76 & $\begin{array}{l}\text { Parent } \\
-1 \text { hour }\end{array}$ & $\begin{array}{l}2 \text { teachers } \\
-1 \text { hour } \\
\text { (individual } \\
\text { interviews) }\end{array}$ & Yes \\
\hline
\end{tabular}

VIDEO JOURNAL OF EDUCATION AND PEDAGOGY 4 (2020) $\quad \mathbf{1 - 2 8}$ 


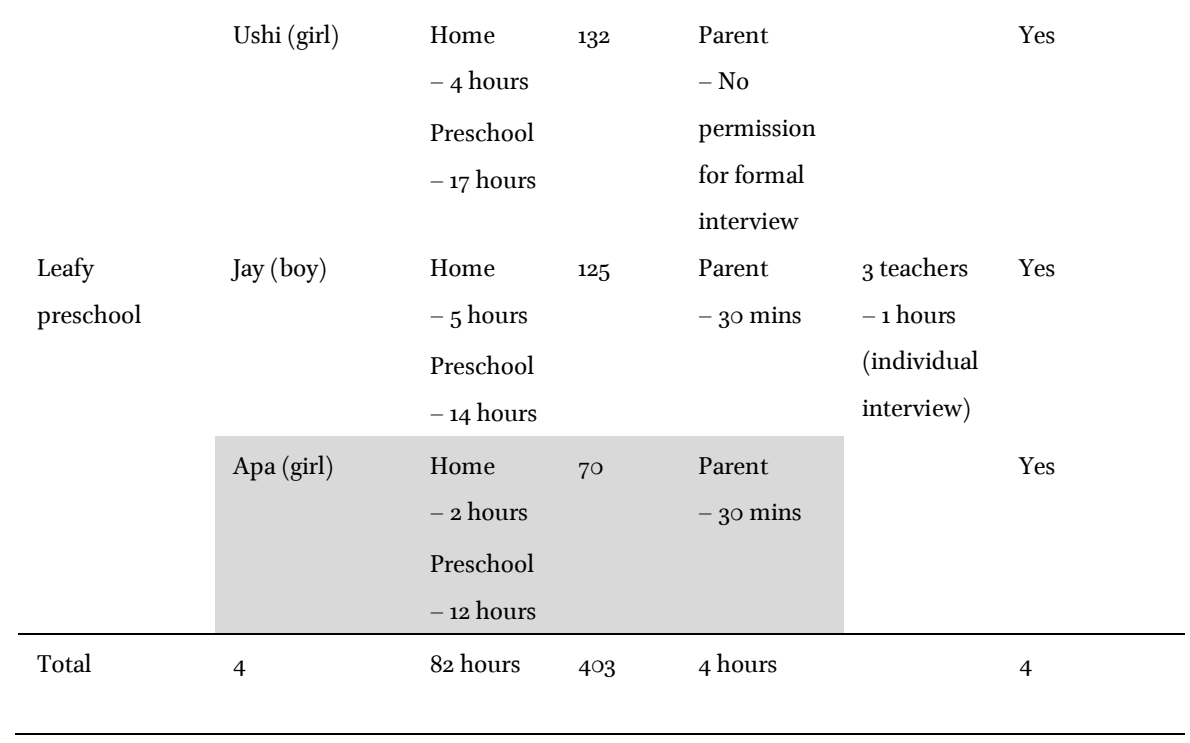

The data referred in this chapter is about a focus child, Apa (highlighted in Table 1), who is 4 and half years old. Apa has an older sister aged 13 years old. As well as English being- their second language, they speak Gujrati (is an Indo-Aryan-language-native to the Indian state of Gujarat) at home. Her favorite play is to play with Barbie doll in imaginative role play.

Apa attends in a Leafy long day care centre (pseudonym is used) four days a week. The centre is located in South East Victoria and is funded by state and federal governments. It is a multicultural centre that is situated in a small suburb with people from diverse cultural backgrounds. Most of the teachers have a bachelor and diploma degree in early childhood education. To establish a play-based pedagogical practice in their centre, all of the teachers follow the Australian national framework Early Years Learning Framework (EYLF) (DEEWR 2009) for setting up the activities, and evaluating the children's learning. Teachers follow the Reggio Emilia approach (Hewett, 2001) but their main focus is play-based learning. They mainly use the learning story method to document children's development and learning. They follow the 'planning cycle' which is proposed by National Quality Standard (NQS) in Victoria. They use still camera, and field notes methods for collecting information from children. The information provided by parents also helps teachers to prepare the learning journal of individual children in order to share learning stories with parents.

To find out how the different positions of the camera and how video recording gave opportunity to the researcher to take active position in the play, there are number of video clips of four focus children that were 
analysed by using Hedegaard's (2008c) three level of interpretations e.g. common sense, situated practice and thematic. In first level, author used common sense interpretation to analyse one single video clip by looking closely of logging moments of researcher-research participants' interaction and position in the play activity. At the level of situated practice interpretation, a number of video clips were analysed to find the conceptual pattern of researcher-research participants' (children and parents) interaction and position in the play activity. A standard video software program (iMovie) was used to open the videos and a Word document or Excel file was also opened beside the video to log researcher-child involvement in play. The raw video was analysed by using iMovie maker, where the researcher was able to cut the video in separate segments (see the Figure 2).

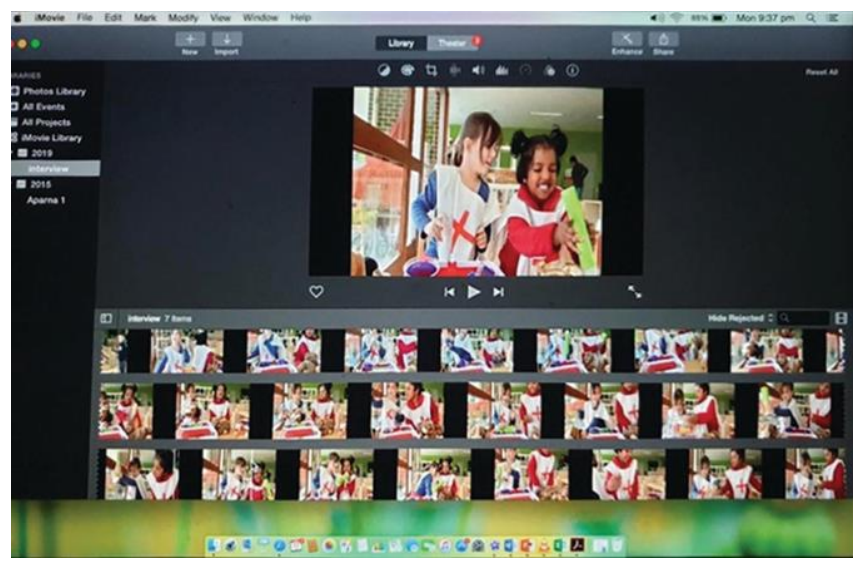

FIGURE 2 Data was analysed by using iMovie software

By using still photos and video records, the authors have developed a diagram of the camera's position for each of the video clips (see the example of positioning camera in Figure 3). Positioning the camera at a different angles helped the researcher to capture the various moments which might not be possible to capture with still camera or only written field notes. The positions of the camera did not only focus on the children and other research participants' action and interaction but also captured the entire play situation. A three-meter radius marker around the child/ren was used to measure the physical position of the researcher, the children, parents and the position of the camera in the play situation. The researcher placed the camera within three-meter radius dimension which allowed the camera's

VIDEO JOURNAL OF EDUCATION AND PEDAGOGY 4 (2020) $\quad \mathbf{1 - 2 8}$ 
lens to capture a certain area of the play situation. Even though in some videos, the researcher did not appear in the film due to positioning behind the camera and capturing the moments, her voice and conversations were captured.

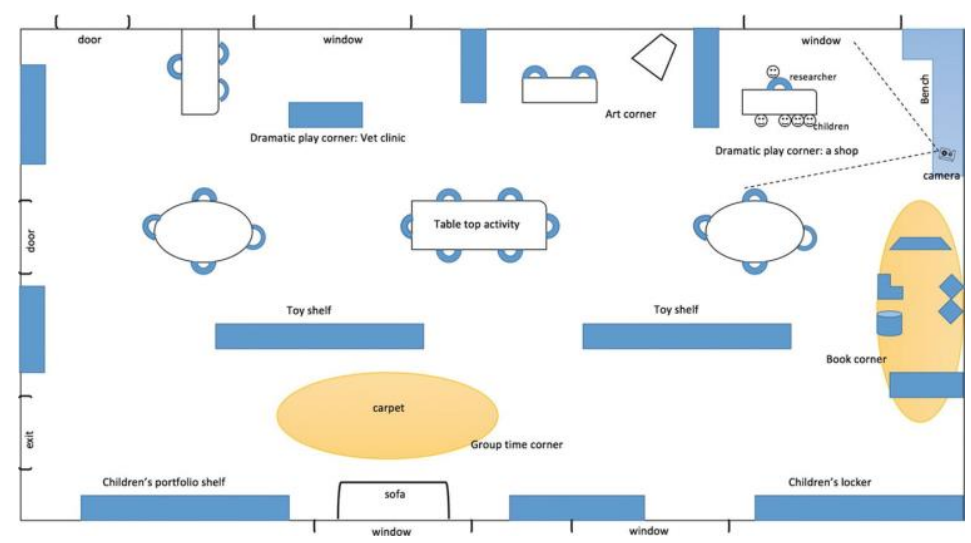

FIGURE 3 The video camera was placed on the bench top

After revisiting the video data, the position of the camera allowed categorization and confirmation of the physical and psychological positioning patterns of researcher and her interactions with children on a number of occasions. This level revealed that by using video camera skilfully and positioning the camera appropriate place, gave the opportunity of the researcher to take an active position in children's play through interaction and action. In thematic level, theoretical concepts were used to see that how a video camera could be a useful tool for researcher to capture the research participants' and the researcher's own motives and demands as well.

\subsection{Ethical Consideration}

Before conducting the research project, the first author of this paper received ethical permission from Department for Education and Early Childhood Development (DEECD) (project number is 2014_002482) and University Human Research Ethics Committee (project number is $\mathrm{CF}_{14} / \mathbf{2 6}_{73}$ 2014001452). To maintain ethical and privacy issues, participants were recruited through the director or manager of the preschools. Non direct contact was made with the children and their families. After receiving permission letter from the manager of the long day care centre, the consent form and explanatory letter were distributed to parents and teachers by the centre manager. The first author gave power point presentations to teachers 
first and the teachers informed the research aim to the families. With the help of lead teacher in preschool, the researcher was able to be allocated focus children and families. After receiving the signed consent form from parents and teachers, the researcher contacted focus families for a home visit at a suitable time.

The lead teacher helped the researcher to explain the research aim to children. The researcher showed some video clips of focus children to parents and children during the home visit. It is important to mention here that the researcher got parental permission before taking video recording and still photographs of the all children in the centre. If the children did not have any photo permission, the researcher did not video record them. It was clearly informed in the explanatory letter that some of the photographic images of the children and adults would be used for publication in a journal article or a book or as teaching materials for researchers. To maintain the privacy issue, the researcher stopped video recording when it was requested by the research participants. The researcher also respected the children's view and the children had opportunity to handle the video camera to explore how it works and what it could capture. To respect the children's and other participants' privacy, the researcher tried to avoid unnecessary zooming in and out of the camera.

\section{$5 \quad$ Findings}

\subsection{Case Example 1: Camera Was Held by the Researcher}

One sunny morning the focus child Apa and her friend Nina (pseudonym is used) were playing near the dramatic play corner. The educator setup a vet clinic for children to engage in imaginative play. The researcher was following the children to capture their interaction and action using a hand held camera. Apa invited the researcher to participate in the play as a vet owner and the researcher did not refuse the proposal but involved herself in the play. The camera was held by the researcher and was in "above the waist" position. The researcher did not stop rolling the camera and without using unnecessary zooming in and out, the camera was steady and capturing the situation in a close proximity.

Apa: Miss A (called by researcher name), where are you going?

Researcher: I am not going anywhere. I am here.

Apa and Nina: You have to be Dora, and these are your pets (showing two soft toys of cat and dog).

VIDEO JOURNAL OF EDUCATION AND PEDAGOGY 4 (2020) $\quad \mathbf{1 - 2 8}$ 
Researcher: Ok, what do I need to do?

Nina: You need to sit down first (the researcher took a seat in front of them)

Apa: They are sick, so I will fix your kitty.

Nina: And I will fix your doggy.

They opened up their medical instrument box. Apa and Nina were using the otoscope to check the animals' ears. The researcher asked question such as that what they are doing with this otoscope and they said that they need the otoscope to check the ears of the pets. Then Apa borrowed a reflex hammer from Nina and used it to check the motor reflex of the cat. She was hammering the cat very roughly, so Nina stopped her and said to be more gentle with the cat. They started to having conversation with the researcher and telling her that what they were doing with the pets. After a while they pretended to feed and gave a bath to the pets. They found an empty shampoo bottle in the medical instrument box which actually motivated them to turn the scenario from vet clinic to grooming pets. After a while they gave the pets back to the researcher and said "they are ok now, you can go home". However, at the end of this play, the researcher did not stop rolling the camera rather captured their transitional moment from one play situation to another play situation.

Above dialogues of the case example 1 shows that the researcher was invited by the children to take a role in the play. The children put demands upon the researcher to be a play partner, as it seems they were looking for a person to take the pet owner character of the play. As a cultural-historical researcher, the researcher did not refuse the invitation and took the pet owner role in the play (Hedegaard 2008b). Their dialogues, facial expressions, negotiation, and transitional moment were filmed by the researcher. Although the researcher was in a pet owner role, but she was filming the entire situation simultaneously. Similar to Quiñones (2014), the researchers found that the position of the camera of "above the waist" allowed them to capture the play moments, make eye contact with children, interact effectively and act as a play partner (p. 118). Using a video camera actually gave them the opportunity to capture children's emotional excitement, facial expressions, and conversation without stopping the camera (see Figures $4,5 \& 6$ ). For example, first four pictures in Figure 4 show how they expressed their different emotional feelings by showing various facial expressions for examples through smile or expressing surprise. They maintained eye contact with the researcher while interacting with her.

VIDEO JOURNAL OF EDUCATION AND PEDAGOGY 4 (2020) $\quad$ 1-28 

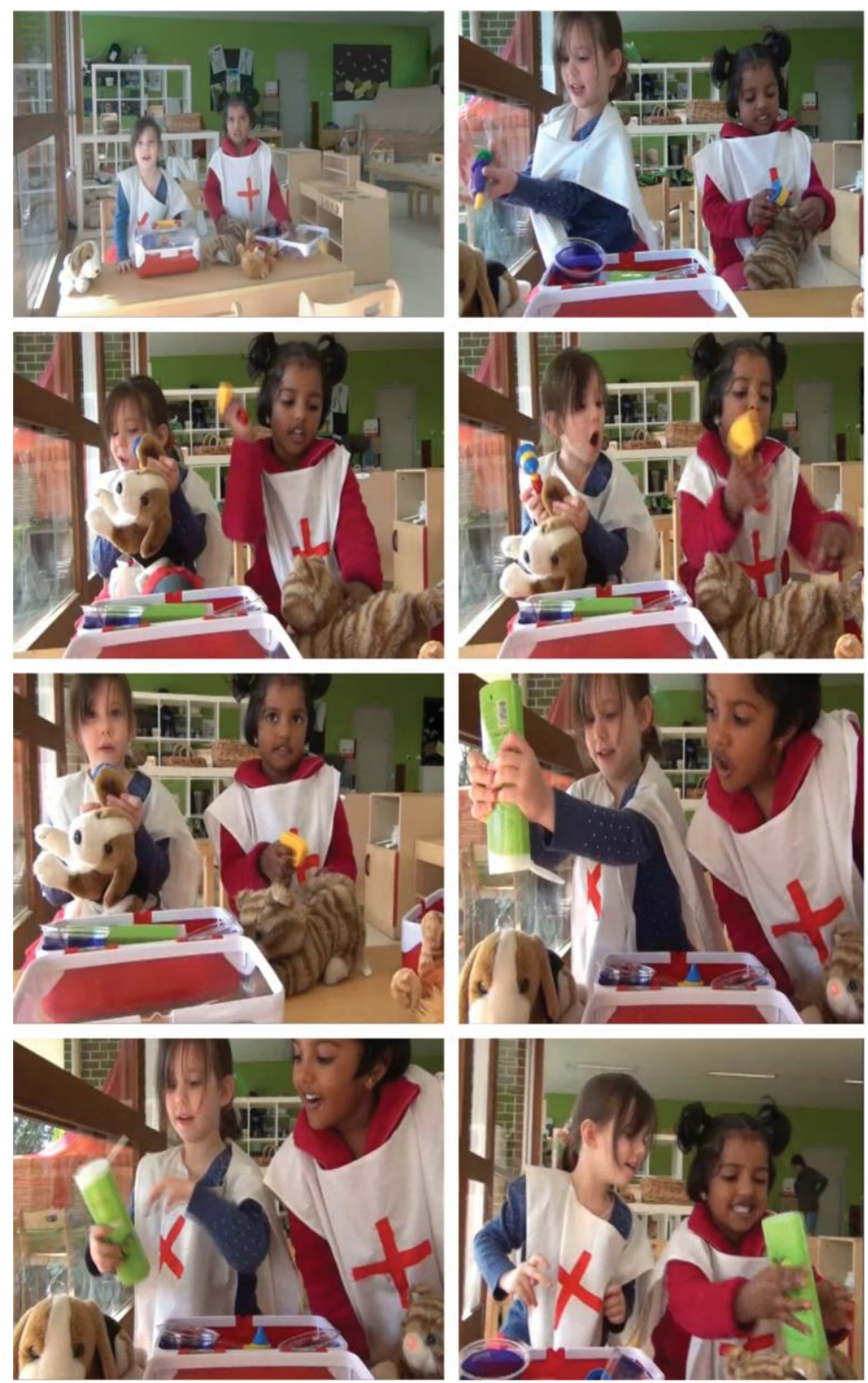

FIGURE 4 Various moments of Apa's imaginative vet play were captured by hand handle camera

VIDEO JOURNAL OF EDUCATION AND PEDAGOGY 4 (2020) $\quad \mathbf{1 - 2 8}$ 


\subsection{Case Example 2: Camera Was Placed on the Bench Top}

Apa and a group of children (Nina, Rosie and Maria, pseudonyms are used) were playing mummy, baby and shop keeper role play in the dramatic play corner. They were negotiating with each other about distributing the characters of the play. Apa proposed to be the mother and all other friends would take baby and dog roles. Now she is looking for someone who could be a shopkeeper in their play. So, she asked the researcher to be the shop keeper.

Apa: Miss A (the researcher), can you be the shop keeper, please?

Researcher: ok, what do I have to do?

Apa: You will need to find this sign (showing the researcher the bar code of the yogurt container) from the box and touch near to the machine and it will make sound "beep" and put the box on the other side.

Researcher: Ok, it is a good idea.

Then the researcher kept her camera on the top of the bench and she made sure that the camera's lens could focus on the actual play scenario. The camera was within a three-meter radius which allowed her to capture the entire scenario of the play situation. She explained the role of the shopkeeper to the researcher again. The researcher was following their instruction and facilitating as a play partner by scanning the bar code of each of the grocery items. The researcher was making "beep" sound like Apa. Apa was putting them in the trolley and other children were helping her. Nina was pulling the trolley from her. She stopped Nina and said

Apa: You can't be angry and you can't do this in the shopping centre, ok.

Apa was making sure that each of the item was scanned properly before putting them in the trolley and each time she was asking the researcher if she had scanned them properly. After that she gave money to the shop keeper and said bye before leaving the place.

In this play scenario it showed that a lot of dramatic collision happened through their affective emotional interaction and action. For example, Apa was in leading position from the beginning of the play and she distributes role for others. She created the actual play scenario by herself and put demand upon everyone to be engaged in the play. Her demand to the researcher of taking a shop keeper role and asking Rosie to take baby's position, motivated everyone to take an active position in the play. This case

VIDEO JOURNAL OF EDUCATION AND PEDAGOGY 4 (2020) $\quad$ 1-28 
example shows, Apa has a clear understanding of what to do as a shopkeeper or as a customer in real life. Even though the researcher knows how to play a shop keeper role, she asked each time before taking any action which shows her motivation to keep herself in a researcher position without taking leads or authority from children (Hedegaard 2008b). Apa also asked Nina to behave in the shopping center as it is not acceptable behavior in the public place. A lot of emotional engagement between the researcher and children was established through this dramatic play.
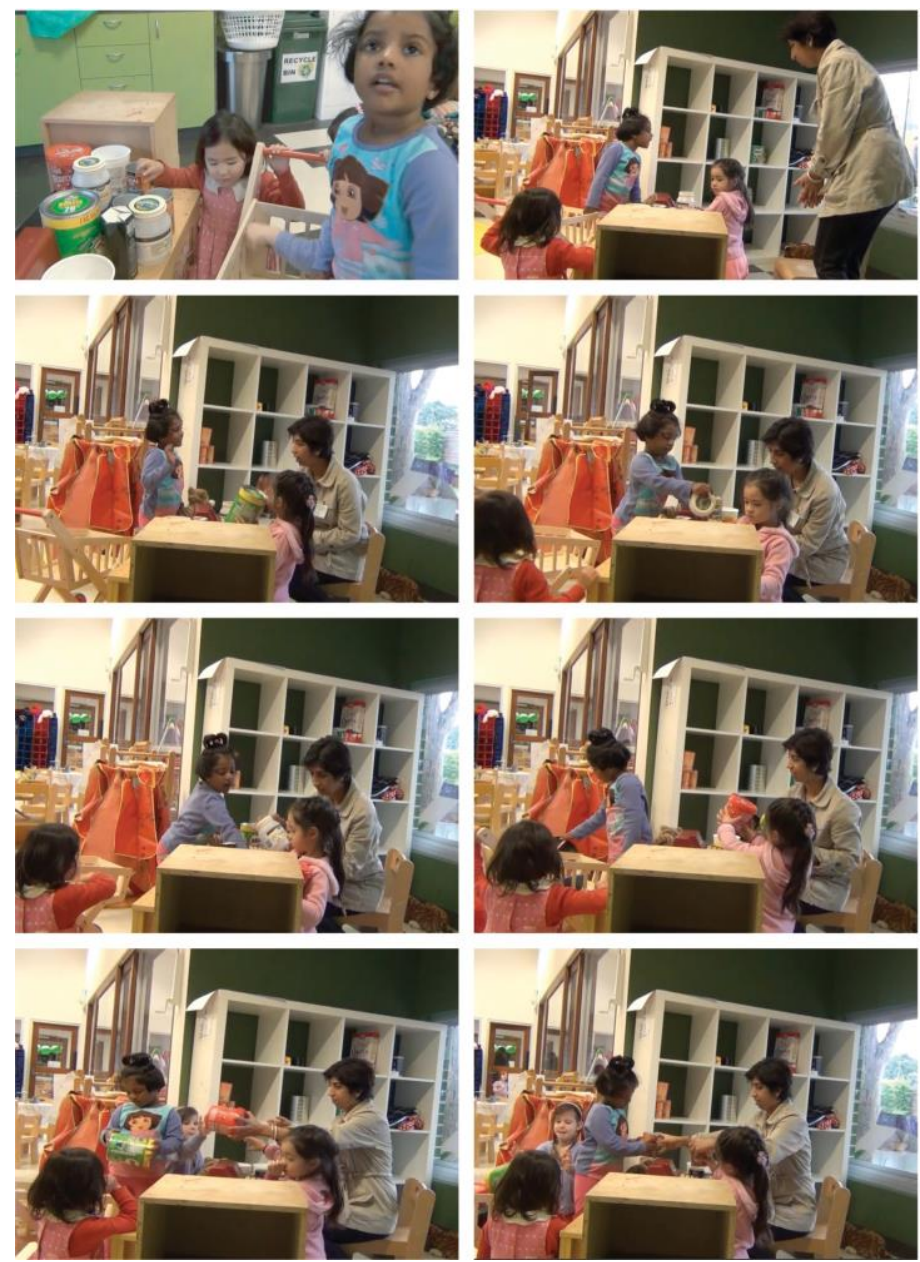

FIGURE 5 Various moments of Apa's imaginative shop keeper play were captured by camera placed on the bench top 
Apa was the leading position when distributing everyone's roles. She was going in and out of the play (Kravtsov and Kravtsova 2010) each time when it was necessary to show the researcher how to scan the grocery items. Pretending to be a mother, she was also concerned about Nina's behavior and asked Nina to behave well in the shop which shows her competency in extending the play. To develop the play, she did not hesitate to ask researcher to be a play partner. The evidence appears in video that the researcher was active and skilfully placed the camera while taking part in children's play. The researcher's intention was to develop a good relationship with the research participant by engaging in the play and simultaneously keep recording the situation without shutting the camera off.

\subsection{Case Example 3: Camera Was Placed on the Tripod}

This case example was captured during the Apa's home visit. She was playing a card game with her elder sister. After a certain period of time, she proposed that the researcher and her mother be play partners in their game. One camera was placed on a tripod and another camera was being held by a research assistant. The camera was within a three-meter radius which captured the entire scenario of the play situation.

Apa: Miss A, you won't be able to go home, you need to play with us. We will play the card game together.

Researcher: Ok, Apa, I will play with you, please tell me what do I need to do.

Apa: You will pick two cards and match them together. I will go first. And then Miss A, my amma (in Gujrati language, means mother) and my akka (means sister) will take turn. Ok?

We all agreed on her decision and started the game. She was very happy when she was able to match the first two cards which was evident the images below captured by the tripod camera. Her facial expression of joy was captured by the video camera. Later on when the researcher was out of the field, she took the screen shots of those moments which is evident in images below (see Figure 5). It is also evident in these images that all the family members including Apa appreciated the researcher when she was able to match a pair of cards. Apa also did not forget to show empathy to her mother when her mother could not match the cards the first instance. After finishing the game when the researcher wanted to leave, Apa became a bit sad and upset to let the researcher go which is evident in the last image of the series of images in Figure 6.

VIDEO JOURNAL OF EDUCATION AND PEDAGOGY 4 (2020) $\quad$ 1-28 
The above case example shows another invitation that the researcher received from the focus child while filming her in a home environment. The child took a leading position to invite all the participants including the researcher in her matching card game. A lot of emotional expressions were exchanged between the players in this scenario (see Figure 6). The child shows her empathy, joy and sadness using various emotional expressions in this scenario. These kind of emotional expressions were only able to be captured by the video camera (Li 2014; Quiñones 2014). Positioning the camera on tripod gave the opportunity to the researcher to be an active play partner and responsive to the child's invitation. The researcher did not ignore the child's invitation instead developed a warm relationship with the research participants and by keeping her position as a cultural-historical researcher, she joined in their group game. Her active position being physically and physiologically involved in the group game, gave the researcher the opportunity to understand the motive orientation of the child. To fulfil her motive orientation of engaging the researcher in her play and building a friendship relationship, Apa put a demand upon researcher and asked her to join in the game. The family members of the child also accepted the researcher's position in their play which created a warm welcoming environment for the researcher to continue filming. To fulfill her own demand of capturing Apa's play based learning situation in close proximity, the situation provoked the researcher to be an active play partner of their play. 

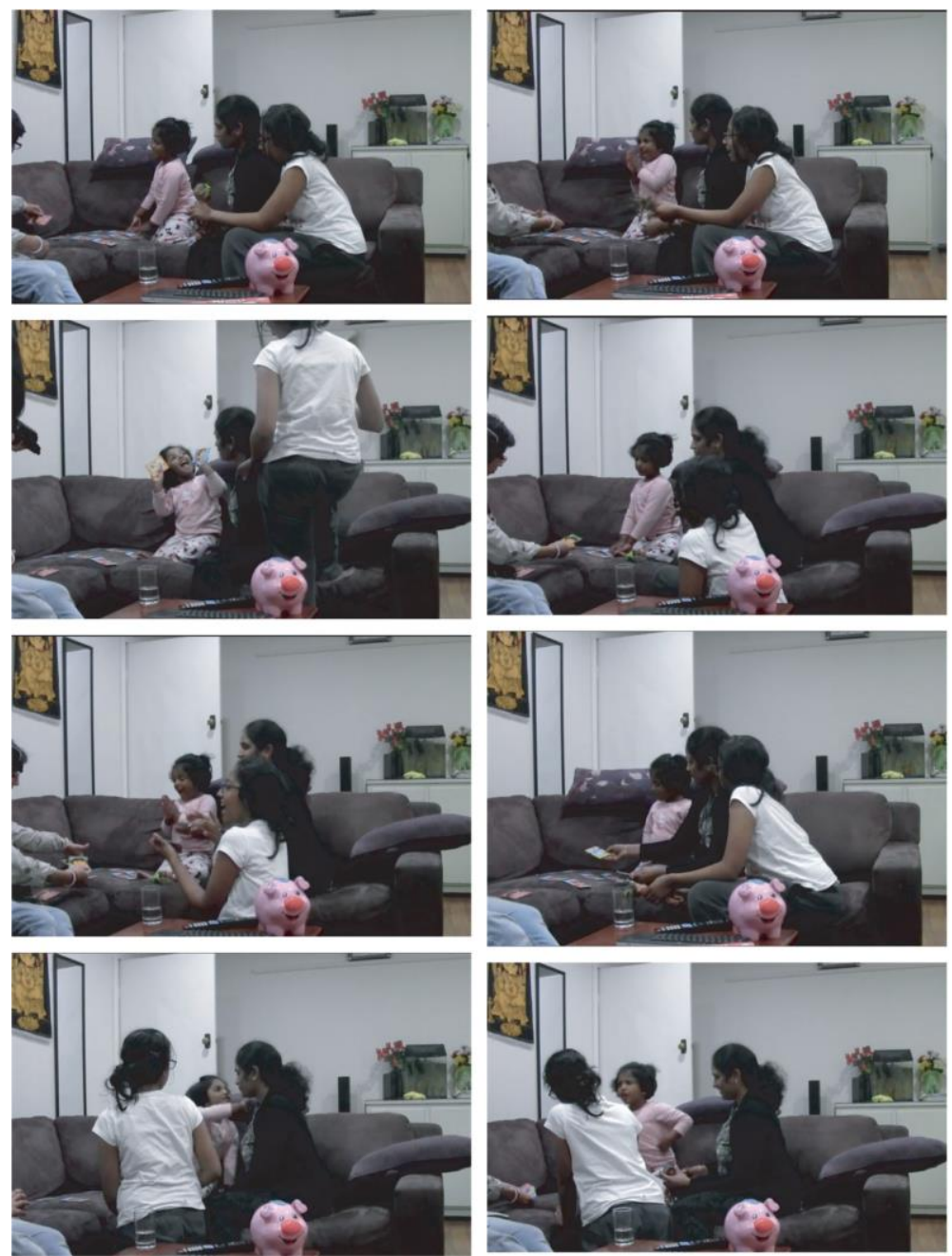

FIGURE 6 Various moments of Apa's memory game with family were captured by the tripod camera

\section{Discussion}

There are two findings in this study. The first finding shows positioning the video camera in a different way in different situations supported the researcher to continue the filming. By using video technology, the researcher was able to develop warm relationships with the participants and understand their motives and demands by being physically and 
psychologically part of the play and also was able keep maintaining her own intention as a researcher. It has also been found in this paper that a researcher needs to be skilled in the art of filming and positioning the video camera while simultaneously taking part in children's play and collecting data (double-ness approach) which an important criterion for CHT research to study in natural settings. In particular, each of the scenarios show the researcher was skilful in capturing the transitional moments from being the researcher to being an active play partner. The aim of this paper was to find out the research participants' motives and demands, and how the researcher was able to shift her role by considering the double-ness approach. The video camera was a helpful experimental tool in which to fulfil the research aim (see Figures 4, 5 \& 6). Now if we refer back to Figure 1, in field research, we made sure that we had a clear understanding about the theoretical concepts of "motives and demands" and that the "double-ness approach" (Hedegaard 2012) and contextual knowledge of how to take double roles by respecting the institutional practice.

In cultural-historical research, the researcher is not in passive position rather is an active participant who has some role in field research. Fleer (2014) argued "In digital video research this double-ness is captured explicitly by not turning off the video camera when the researcher interacts with the participants, but also when the researcher seeks meaning during analysis where the researcher's role is considered when viewing the digital video data" (p.26). In this study we have found that after receiving sudden invitation from the children, the researcher needed to quickly make a decision on how to be actively involved without stopping the camera. In the first example, researcher's decision of holding the camera and simultaneously interacting with children gave her the opportunity to develop her understanding about children's perspectives. The researcher was able to fulfil the child's demands of involving her in the play and kept her own motivation of understanding their play through sustained shared conversation as an owner of the pet. Video camera gave the opportunity not only to capture the moment of children's engagement and interaction, but also their emotional expression and collectively extend the play situation in relation to social context. Goldman (2007) argued that "Video representations seem to be a different kind of re-presentation than textual representations. They display and illustrate a person's expression and experience in the context of a community as an event is taking place" (p. 16). Children's motive for engaging in vet clinic pretend play was culturally constructed and they bring this experiences from their real life situation (Vygotsky 2004).

VIDEO JOURNAL OF EDUCATION AND PEDAGOGY 4 (2020) $\quad \mathbf{1 - 2 8}$ 
In the second, and third example it shows that the researcher needed to place the camera somewhere in an appropriate place where the camera could capture the situations and she could take active role by receiving an invitation from the child. Therefore, the researcher's quick action of putting the camera on the bench top or tripod allowed her to physically and psychologically involve herself inside the play as a play participant. In first example, the researcher was only able to interact but the last two examples show that video technology actually allowed the researcher to be an active player through her action too, for example, scanning the grocery items in second video and playing matching card game in third video. Overall, positioning the camera in three different positions, the researcher was able to be physically and psychologically in close proximity to the children's play, which allowed her to be emotionally engaged with them and understand participants' perspectives. Being involved in the play the researcher got the opportunity to understand their motives and demands. The children's motive orientation was to create a playful environment by inviting people in their play. The video data shows that each time the researcher was involved in the focus child's play because of fulfilling the focus child's demand of engaging the researcher in her play. The reason for inviting the researcher may be that the researcher was in close proximity and the focus child Apa was able to have a relationship with the researcher, so that they would feel comfortable to play with her. However, the researcher also did not dismiss her motive orientation of rolling the camera to meet the demands of capturing some significant moments of children's play to complete the research project. The evidence shows that researcher and the research participants actually put demands upon each other (Quiñones 2014).

The finding shows that the visual methodology helped the researcher to capture the moments of various play situations and transitions which was not possible by using field notes or only still pictures. The researcher did not take initiative to teach the name of the medical instruments in example 1 or teach how much money the children will pay to shop keeper in example 2, because she was not allowed to take a leading role or an instructor role as a researcher rather her role was to follow the 'balancing act' as an active community member (Hedegaard 2008a; Quiñones 2014). But first these two examples show, that the adults have the opportunity to create a play based learning approach by engaging effectively and actively in children's play by taking an active role. As a cultural-historical researcher, the role of the researcher in the classroom was just only to take a play partner role without taking teacher's authority. So, the researcher did not tell the children what 
they need to do as the teacher of the class or take important decisions in relation to learning.

TABLE 2 Positioning of the camera and its dynamic relationship with research participants

\begin{tabular}{|c|c|c|c|}
\hline $\begin{array}{l}\text { Positioning of the } \\
\text { video camera }\end{array}$ & $\begin{array}{l}\text { Double-ness } \\
\text { approached of the } \\
\text { researcher }\end{array}$ & $\begin{array}{l}\text { Motive and demands } \\
\text { of the participants }\end{array}$ & $\begin{array}{l}\text { Motive and demands } \\
\text { of the researcher }\end{array}$ \\
\hline $\begin{array}{l}\text { Camera was holed by } \\
\text { the researcher } \\
\text { (preschool setting) }\end{array}$ & $\begin{array}{l}\text { The researcher was in } \\
\text { double positions, she } \\
\text { skillfully continued } \\
\text { filming and took part in } \\
\text { the imaginative play } \\
\text { through interaction }\end{array}$ & $\begin{array}{l}\text { Apa's motive was to } \\
\text { find someone to be a } \\
\text { pet owner and the } \\
\text { demand created } \\
\text { through the play } \\
\text { condition, she put } \\
\text { demand on the } \\
\text { researcher to take the } \\
\text { role of the pet owner }\end{array}$ & $\begin{array}{l}\text { The researcher's motive } \\
\text { was to create warm } \\
\text { relationship with } \\
\text { participant/s, therefore } \\
\text { she interacted and } \\
\text { acted as a play partner } \\
\text { by taking part in the } \\
\text { play. Her intention of } \\
\text { understanding research } \\
\text { participants' motives }\end{array}$ \\
\hline $\begin{array}{l}\text { Camera was placed on } \\
\text { the bench top } \\
\text { (preschool setting) }\end{array}$ & $\begin{array}{l}\text { The researcher was in } \\
\text { double positions, she } \\
\text { skillfully continued } \\
\text { filming and took part in } \\
\text { the imaginative play } \\
\text { through action and } \\
\text { interaction }\end{array}$ & $\begin{array}{l}\text { Apa's motive was to } \\
\text { find someone to be a } \\
\text { shop keeper and the } \\
\text { demand created } \\
\text { through the play } \\
\text { condition, therefore } \\
\text { she put demand on the } \\
\text { researcher to take the } \\
\text { role of the shop keeper }\end{array}$ & $\begin{array}{l}\text { influenced by the } \\
\text { institutional demand of } \\
\text { collecting data for } \\
\text { conducting her } \\
\text { research. }\end{array}$ \\
\hline $\begin{array}{l}\text { Camera was placed on } \\
\text { the tripod (home } \\
\text { setting) }\end{array}$ & $\begin{array}{l}\text { The researcher was in } \\
\text { double positions, she } \\
\text { skillfully continued } \\
\text { filming by keeping the } \\
\text { camera on the tripod } \\
\text { and took part in the } \\
\text { group game through } \\
\text { action and interaction }\end{array}$ & $\begin{array}{l}\text { Apa and her family had } \\
\text { opportunity to involve } \\
\text { researcher in their card } \\
\text { game which motivated } \\
\text { Apa to continue the } \\
\text { play and she put } \\
\text { demands not only to } \\
\text { the researcher but also } \\
\text { other family members } \\
\text { to take part in the } \\
\text { game. }\end{array}$ & \\
\hline
\end{tabular}

VIDEO JOURNAL OF EDUCATION AND PEDAGOGY 4 (2020) $\mathbf{1 - 2 8}$ 
Overall, in researcher position, her motive was to film the play situation. In contrast, in a play partner position, she wanted to understand the focus child's motive orientation in close physical proximity which only was possible by taking a role inside the play (Devi et al. 2019). The invitation from the focus child to join in their play actually opened up the possibility of the researcher to join in their conversations, and understand their perspectives closely. Table 2 shows, positioning the camera in three different positions, the researcher was able to take double positions as a researcher and active play partner. The researcher and research participants' demands and motives were also captured by the video technology which might not have been possible with traditional ways of data collection. However, holding the camera and simultaneously focusing the camera in the correct position during the transitional moment of shifting from the researcher position to play partner position was not an easy task for the researcher. Each time while conducting the video recording and focusing of the lens for capturing the transitional and dramatic moments and simultaneously taking active participant's role inside the play, the researcher needed to be careful of video recording by managing ethical issues such as not to take video of those children and teacher who did not have consent or not to do unnecessary zooming in and out. If the researcher stopped filming, she could lose capturing some interesting moments during the transitions and also could lose the participants' interaction and emotional expressions in the play. But understanding children's interests and motives by engaging in sustained shared conversation is one of the primary focus for educators in EYLF in Australia (DEEWR 2009). Most of the researchers from cultural-historical theoretical research showed the importance of using video technology for capturing young children's emotions, interaction and engagement in everyday activities in different settings (Chen and Fleer 2015; Hao 2016; Li 2014; Quiñones and Fleer 2011; Sikder and Fleer 2015; White 2011). However, except for Quiñones (2014), none of the authors talked about the researcher's role and positioning inside the children's play while filming the play moments. Moreover, in our literature review, the authors of this paper did not find any research shows how to take position and handle the camera skillfully while simultaneously taking part in children's play. The current research shows that skilfully positioning camera in various positions, allows the researcher to take active part in children's play, to transition from one role to another role and to understand the children's perspectives by being in close proximity without taking authority away from the children.

VIDEO JOURNAL OF EDUCATION AND PEDAGOGY $4(2020) \quad$ 1-28 
The paper shows that using the video camera helped the researcher to capture the transitory moments, children's interaction process and allowed them to take double positions in children's play. This paper has the possibility to pass the message on to all early childhood stakeholders that a video camera could be an effective research tool as well as cultural tool to capture important moments of children's involvement in the play.

According to the National Quality Standard (NQS) area 1, each child's learning and development needs to be documented properly emphasizing that the educators need to gather information about the child to do effective program planning. Taking this into account the use of video is an acceptable way of creating documentation. Documenting using paper based methods at the same time of children's play, limits the opportunities of the educators to become actively involved in their play. We would like to advocate that future research needs to focus on to finding out how video technology could help educators to do self assessment or evaluation and give them a chance to be critical of their own practice by going back to the video again and again to make a more meaningful judgment; and how video technology could give the opportunity to educators to do effective planning and modify their planning as a mini researcher. To sum up, we argue that video technology has a substantial possibility for the researchers and educators to capture significant moments and provide reliable evidence of a child's development and learning.

\section{Acknowledgements}

We would like to express our sincere gratitude to the children and parents who participated in this study. We would like to acknowledge the University ethics committee ( $\mathrm{CF}_{14} / 2673$ - 2014001452) and Department of education (2014_002482) for giving approval to conduct this research project.

\section{References}

Brian, E. (2010). Playing with children, answering with out lives: A Bakhtinian approach to coauthoring ethical identities in early childhood. British Journal of Educational Studies, 58(2):197-211.

VIDEO JOURNAL OF EDUCATION AND PEDAGOGY 4 (2020) $\quad \mathbf{1 - 2 8}$ 
Chen, F. (2015). Parents' perezhivanie supports children's development of emotion regulation: A holistic view. Early Child Development and Care, 185(6): 851-867.

Fleer, M. (2008). The relations between cultural-historical theory, methodology and digital video methods. In: Hedegaard, M. and Fleer, M. (eds.) Studying children: A cultural-historical approach. Open University Press, New York.

Fleer, M. and Veresov, N. (2018). A Cultural-Historical Methodology for researching early childhood education. In: Fleer, M. and van Oers, B. (eds.) International Handbook of Early Childhood Education. Springer, pp. 225-250.

Fleer, M. and Ridgway, A. (eds.) (2014). Visual methodologies and digital tools for researching with young children: transforming visuality. In: International perspectives on early childhood education and Development 10. Springer, Dordrecht.

Department of Education, Employment and Workplace Relations (DEEWR) (2009). The early years learning framework for Australia, Belonging, Being, Becoming. Retrieved from Department of Education, Employment and Workplace Relations (DEEWR):

http://www.deewr.gov.au/Earlychildhood/Policy_Agenda/Quality/Documents/Fi nal\%2oEYLF\%2oFramework\%2oReport\%2o-\%2oWEB.pdf.

Devi, A., Fleer, M. and Li, L. (2018). "We set up a small world": Preschool teachers' involvement in children's imaginative play. International Journal of Early Years Education. Published online, doi:10.1080/og66976o.2018.1452720.

Devi, A., Fleer, M. and Li, L. (2019). Transition between child-initiated imaginative play and teacher-initiated activity: An analysis of children's motives and teachers' pedagogical demands in a preschool context. In: Hedegaard, M. and Fleer, M. (eds.) Children's transition in everyday life and across institutions. Bloomsbury Publisher.

Goldman, R. (2007). Video representations and the perspectivity framework: Epistemology, ethnography, evaluation, and ethics. In: Goldman, R., Pea, R., Barron, B. and Derry, S.J. (eds.) Video research in the learning sciences. Mahwah: Lawrence Erlbaum Associates, pp. 3-38.

Hao, Y. and Fleer, M. (2016). Creating collective scientific consciousness: A culturalhistorical study of early learning about Earth and space in the context of family imaginary play. Asia-Pacific Journal of Research in Early Childhood Education $10(2)$ : 93-124.

Hedegaard, M. and Fleer, M. (2008). Studying Children. A Cultural-Historical Approach. Maidenhead, England: Open University Press.

Hedegaard, M. (2008a). A cultural-historical theory of children's development. In: Hedegaard, M. and Fleer, M. (eds.) Studying Children. A Cultural-Historical Approach. New York: McGaw Hill Open University Press, pp. 10-29.

VIDEO JOURNAL OF EDUCATION AND PEDAGOGY 4 (2020) $\quad$ 1-28 
Hedegaard, M. (2008b). Developing a dialectical approach to researching children's development. In: Hedegaard, M. and Fleer, M. (eds.) Studying Children. A CulturalHistorical Approach. New York: McGaw Hill Open University Press, pp. 30-45.

Hedegaard, M. (2008c). Principles for interpreting research protocols. In: Hedegaard, M. and Fleer, M. (eds.) Studying Children. A Cultural-Historical Approach. New York: McGaw Hill Open University Press, pp. 46-64.

Hedegaard, M. (2008d). The role of the researcher. In: Hedegaard, M. and Fleer, M. (eds.) Studying Children. A Cultural-Historical Approach. New York: McGaw Hill Open University Press, pp. 202-207.

Hedegaard, M. (2012). Analyzing children's learning and development in everyday settings from a cultural-historical wholeness approach. Mind, Culture and Activity $19(2): 127-138$.

Hedegaard, M. and Fleer, M. (2013). Play, Learning and children's development: Everyday life in families and transition to school. New York: Cambridge University Press.

Hewett, V. (2001). Examining the Reggio Emilia Approach to Early Childhood Education. Early Childhood Education Journal 29(2), pp. 95-100.

Johansson, E. and White, J. (eds.) (2011). Introduction: Giving Words to Children's Voices in research. In: Educational Research with Our Youngest. Voices of Infants and Toddlers. Springer, Dordrecht.

Kravtsov, G.G. and Kravtsova, E.E. (2010). Play in L.S. Vygotsky's Nonclassical Psychology. Journal of Russian and East European Psychology 48(4):25-41.

Li, L. (2014). A visual dialectic methodology-using a cultural historical analysis to unearth the family strategies in children's bilingual heritage language development. In: Fleer, M. and Ridgway, A. (eds.) Visual methodologies and digital tools for researching with young children: Transforming visuality. Switzerland: Springer, pp. $57-82$.

Lynn, E.C. (2015). Layers of discourse in preschool block play: An examination of children's social interactions. International Journal of Early Childhood 47: 267-281.

Quiñones, G. and Fleer, M. (2011). "Visual Vivencias": A cultural-historical tool for understanding the lived experiences of young children's everyday lives. In: Johansson, E. and White, J. (eds.) Educational research with our youngest: Voices of infants and toddlers. Springer, Netherlands, pp. 107-129.

Quiñones, G. (2014). A visual and tactile path: affective positioning of researcher using cultural-historical visual methodology. In: Fleer, M. and Ridgway, A. (eds.) Visual methodologies and digital tools for researching with young children: Transforming visuality. Switzerland: Springer, pp. 111-128.

Quiñones, G. (2016). 'Visual Vivencias' to understand subjectivity and affective connection in young children. Video Journal of Education and Pedagogy 1(3). DOI 10.1186/s40990-016-0oo4-1.

VIDEO JOURNAL OF EDUCATION AND PEDAGOGY 4 (2020) $\quad \mathbf{1 - 2 8}$ 
Rogoff, B. (2003). The Cultural Nature of Human Development. Oxford: Oxford University Press.

Ridgway, A. (2018). Video capture of symbolic activity in toodler initiated play. Video Journal of Education and Pedagogy 3(1). DOI 10.1186/s40990-017-0013-8.

Sikder, S. and Fleer, M. (2015). The relations between ideal and real forms of small science: conscious collaboration among parents and infants-toddlers. Cultural studies of Science education. (n.p.).

Veresov, N. (2014). Method, methodology and methodological thinking. In: Fleer, M. and Ridgway, A. (eds.) Visual methodologies and digital tools for researching with young children: Transforming visuality. Switzerland: Springer, pp. 215-228.

Vygotsky, L.S. (1978). Mind in Society: The development of higher psychological processes. Cambridge, MA: Harvard University Press.

Vygotsky, L.S. (1997a). Volume 4 The History of the Development of Higher Mental Functions. Plenum Press, New York.

Vygotsky, L.S. (1997b). Volume 3 Problems of the theory and history of psychology. Plenum Press, New York.

Vygotsky, L.S. (2004). Imagination and Creativity in Childhood. Journal of Russian and East European Psychology 42(1): 7-97.

White, E.J. (2011). 'Seeing' the toddler: Voices or voiceless? In: Johansson, E. and White, E.J. (eds.) Educational research with our youngest: Voices of infants and toddlers. Springer, Dordrecht, pp. $63^{-86 .}$

White, E.J., Redder, B. and Peter, M. (2013). To be or not to be: Is that the question in infant play? The First Years: Nga Tau Tuatahi New Zealand Journal of Infant and Toddler Education 15(2): 16-20.

White, E.J. (2016). More than meets the "I": A polyphonic approach to video as dialogic meaning-making. VideoJournal of Education and Pedagogy $1(6)$.

White, E.J., Peter, M. and Redder, B. (2019a). Infant and teacher dialogue in education and care: A pedagogical imperative. Early Childhood Research Quarterly 30: 160173.

White, E.J., Redder B.S., Manser, B.D., Geddes, C., Hjorth, C. and Rogers, A. (2019b) Age-responsive pedagogies: 'preschool' teachers interrogate their dialouges with and about 2-years-olds. Teaching and Learning Research Initiative project report.

VIDEO JOURNAL OF EDUCATION AND PEDAGOGY 4 (2020) $\mathbf{1 - 2 8}$ 